EMOTIONAL SELF-MANAGEMENT

IN ACADEMIA 
This page intentionally left blank 


\title{
EMOTIONAL SELF-MANAGEMENT IN ACADEMIA
}

\author{
MARILENA ANTONIADOU \\ Manchester Metropolitan University, UK \\ AND \\ MARK CROWDER \\ Manchester Metropolitan \\ University Business School, UK
}

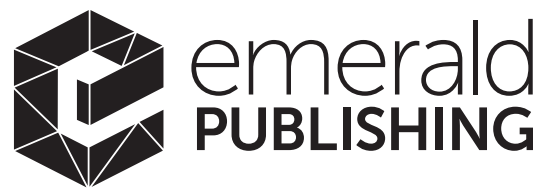

United Kingdom - North America - Japan - India Malaysia - China 
Emerald Publishing Limited

Howard House, Wagon Lane, Bingley BD16 1WA, UK

First edition 2021

Copyright $(0) 2021$ by Emerald Publishing Limited.

All rights of reproduction in any form reserved

\section{Reprints and permissions service}

Contact: permissions@emeraldinsight.com

No part of this book may be reproduced, stored in a retrieval system, transmitted in any form or by any means electronic, mechanical, photocopying, recording or otherwise without either the prior written permission of the publisher or a licence permitting restricted copying issued in the UK by The Copyright Licensing Agency and in the USA by The Copyright Clearance Center. Any opinions expressed in the chapters are those of the authors. Whilst Emerald makes every effort to ensure the quality and accuracy of its content, Emerald makes no representation implied or otherwise, as to the chapters' suitability and application and disclaims any warranties, express or implied, to their use.

\section{British Library Cataloguing in Publication Data}

A catalogue record for this book is available from the British Library

ISBN: 978-1-78973-512-3 (Print)

ISBN: 978-1-78973-511-6 (Online)

ISBN: 978-1-78973-513-0 (Epub)

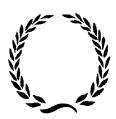

INVESTOR IN PEOPLE 


\section{CONTENTS}

Acknowledgements

vii

Dedications

ix

About the Authors

$x i$

List of Figures and Tables

xiii

1. Introduction

2. Understanding Emotions and Emotion (Self-) Management 7

3. The Emotional Exchanges of Academia 25

4. Self-Managing Academia's Emotional Exchanges 45

5. Epilogue 65

References 69

Index 83 
This page intentionally left blank 


\section{ACKNOWLEDGEMENTS}

Writing this book has been cathartic and liberating, but it has been harder and more rewarding than we could have imagined when we began this process. This book has been our dream for many years and we would like to thank everyone who made it happen.

We owe an enormous debt of gratitude to our participants, all of whom agreed to be interviewed, often at short notice, and who graciously gave up their time to share their thoughts and reflections with us. We know how hard it was to share many of your experiences, and we could see the emotional impact this had on you. But, you shared your thoughts anyway. Without you, our book would lack richness and depth, and would be less compelling. You gave your time selflessly with the intention of helping others. The world is a better place as a result. We cannot thank you all in person, but you know who you are!

We would also like to thank those who reviewed the early drafts of the book, and who gave us detailed and constructive comments. Your suggestions focused our thinking, encouraged us to explore new concepts and improved the structure and scope of the work.

We would like to thank our publishers. Again, there are too many people to name, but particular thanks go to David and Niall for your patience and support. Without your support and guidance this book would never have been possible.

Finally, we would like to thank our families. Thank you George, Sue, Gemma and Laura. Thank you for tolerating us when we spent long hours banging away on our keyboards, and for your patience when we disappeared for hours at a time to conduct interviews. Thank you for listening as we regaled you with tales from our interviews, and for putting your lives on hold as we developed our thoughts. Our book is finally being published. You have helped to make our dream come true.

We thank you all. 
This page intentionally left blank 
Marilena would like to dedicate this book to George and her family. You are my strength.

Mark would like to dedicate this book to Sue, Gemma and Laura. Thank you for your unfailing love and support. 
This page intentionally left blank 


\section{ABOUT THE AUTHORS}

Dr Marilena Antoniadou is a Reader in Management and Organisational Psychology at the Department of People and Performance of Manchester Metropolitan University. She specialises in the role of emotions and emotional (self-)management in the workplace. She is the holder of the Newer Researchers Award for 2015 by the Society of Research into Higher Education. She is also a Senior Fellow of the Higher Education Academy, a Chartered Academic member of the CIPD, a member of the CMI, a Certified Management \& Business Educator and a committee member of North-West committee of The Association for Business Psychology. She has published within the fields of educational management and organisational psychology.

Dr Mark Crowder is Education Lead for the Department of Strategy, Enterprise and Sustainability at Manchester Metropolitan University in the UK. He is also a senior lecturer in Strategy and Business Psychology. He has more than 20 years' management experience, and studied at Liverpool John Moores University and the University of Liverpool before gaining his $\mathrm{PhD}$ in cognitive psychology at the University of Chester. He is a Senior Fellow of the Higher Education Academy and a Fellow of the Chartered Management Institute. Mark's research interests are split between educational management and cognitive psychology. 
This page intentionally left blank 


\section{LIST OF FIGURES AND TABLES}

Figure 4.1. Academics' Emotional Self-Management Strategies.

Table 2.1. Key Terms Relating to of Emotional Exchange. 